\title{
Disaster Management In Kelud Community
}

\author{
Vitaria Wahyu Astuti*, Rimawati \\ STIKES RS Baptis Kediri, Indonesia \\ *vitariawahyu@gmail.com
}

\begin{abstract}
Indonesia is called a disaster laboratory for the whole world this is because all types of disasters have occurred such as natural disasters, non-natural disasters and social disasters. One of the natural disasters that often occurs in Indonesia is Mount erupting, this is because there are 127 active volcanoes and 7 of them are in the East Java region, one of which is Mount Kelud which is in Kediri Regency. The community is one of the resources that can reduce the risk of natural disasters. The purpose of this research was to find out how disaster management in the Kelud community in facing Mount Kelud erupting. The design of this research was a qualitative phenomenological study. The population was the Kelud community in Kepung and Puncu districts. The number of participants was 15 consisting of elements of government, members of TSBD organizations and the community. The data collection process was carried out with online Focus Discussion Group guidelines using the WhatsApp Video Call Group application. Data analysis that had been carried out had identified two important themes in disaster management in the Kelud community, namely the disaster management stage and community activities at the disaster management stage. The Kelud community is a community that is able to live in peace with disasters as evidenced by an understanding of disaster management carried out. Communities who are able to carry out disaster management will be able to reduce the risk that occurs when the disaster occurs.
\end{abstract}

Keywords : Disaster Laboratory, Natural Disasters, Mountain Eruption, Disaster Management, Kelud Community

Received August 25, 2020; Revised September 17, 2020; Accepted September 28, 2020 


\section{STRADA Jurnal Ilmiah Kesehatan}

DOI: $10.30994 /$ sjik.v9i2.427

ISSN: 2252-3847 (print); 2614-350X (online)

Vol.9 No.2 November 2020 Page.1078-1084

\section{BACKGROUND}

Disaster is a series of events that threaten and disrupt human life in general and are caused by natural or non-natural factors and even humans which result in death tolls, environmental damage, loss of property which causes psychological impacts (Law No. 24 of 2007). The types of disasters that exist in Indonesia are natural disasters, non-natural disasters and social disasters, while the natural disasters that often occur in Indonesia are earthquakes, mountain eruption, floods and tornadoes. This is due to the geographical, geological, hydrological and demographic conditions of Indonesia which state that Indonesia is the largest archipelago in the world which has 129 active volcanoes, 3 tectonic plates and Indonesia is also a tropical region so that this condition often results in Indonesia having a high potential for disaster. This is what makes Indonesia known as a Disaster Laboratory (BNPB). Seeing this, it is necessary to carry out disaster management, which is a series of efforts that include the establishment of development policies at risk of disaster, the activities carried out are disaster prevention, emergency response and rehabilitation.

An erupting volcano is one of the natural disasters that often occurs in Indonesia, an overview of East Java Province has 7 active volcanoes, one of which is Mount Kelud. Based on data from the Centre for Volcanology and Geological Hazard Mitigation(2014) the history of Mount Kelud's activity has been recorded since 1000 to date, the first recorded eruption of fatalities was on 22-23 May 1901 but it is not certain the number of death tollsbut on 20 May 1919 it erupted and returned with 5,160 victims. The area around Mount Kelud which had a very bad impact at the time of the eruption was divided into 4 locations, namely Ngancar, Puncu, Kepung and Plosoklaten where these villagesare location close to the crater and are a net for lava flow.

In disaster management, it is necessary to carry out an internal disaster management mechanism known as Community Based Disaster Management (CBDM), namely a disaster management mechanism carried out by the community at the disaster location both individually, family, social organizations and the local community. Community-based disaster risk reduction is an activity carried out with the aim of reducing the threat of disaster and community vulnerability, and increasing the ability of the community to remain alert in the face of disasters and is planned and carried out by the community (Sukmana, Oman., 2018) Community preparedness in disaster management has an important role because it relates to people's knowledge of disaster management and actions taken when a disaster occurs, because preparedness is a good way to reduce the impact of a disaster (Ula, Nur Mas., Sriartha, I Putu., Citra, I Putu Ananda, 2019). The stages of disaster management based on Law No. 24 of 2007 are divided into 4 stages, namely 1) The pre-disaster stage which consists of prevention, mitigation and preparedness activities, 2) The emergency response stage where this stage is carried out in saving death tolls, 3) The rehabilitation phase of activities carried out are physical and non-physical repairs, 4) The reconstruction phase of activities carried out is by rebuilding damaged public infrastructure and facilities (AIPTINAKES Jatim, 2018).

Community is a group of people who live and interact with each other in an area that has strong legal ties and solidarity who have the same goals, locality and needs, for example living in an environment that is equally exposed to the same risks, has both been affected by disasters and at the same time, ultimately have the same concerns and expectations about disaster risk. Disaster Risk Reduction is a systematic approach to identify, assess and reduce disaster risk, which aims to reduce socio-economic vulnerability to disasters and address environmental hazards and other hazards that create 


\section{STRADA Jurnal Ilmiah Kesehatan}

DOI: $10.30994 /$ sjik.v9i2.427

ISSN: 2252-3847 (print); 2614-350X (online)

Vol.9 No.2 November 2020 Page.1078-1084

vulnerability (PERKA, 2012). The Kelud community is a resilient community that is able to adapt and coexist with the Mount Kelud disaster which can erupt at any time. The purpose of this study was to determine how disaster management in the Kelud community when Mount Kelud erupted.

\section{METHODS}

The design of this research was a qualitative phenomenological study with the population was the Kelud community in Wonorejo Village, Kepung District and Kebonrejo Village, Puncu District with a sample size of 15 participants consisting of elements 1) Local village officials represented by the village officials heads of hamlets 2) Chairman and administrators of Regional Disaster Response Teams (RDRT) and 3) Community members who are active in RDRT activities. Data was collected by online Focus Group Discussion (FGD) using WhatsApp Group Video Calls. Data analysis was performed by 1) Describing, 2) Meaning, 3) Categorization, 4) Constants comparative method 5) Connecting categories, while the validity of the data was carried out by confirmability. The research was conducted after obtaining ethical approval from the Health Research Ethics Commission (KEPK) STIKES Kediri Baptist Hospital with letter number 076 / I / VI / EC / KEPK-3 / STIKES RSBK / 2020 and received a recommendation from the National Unity and Political Body of the Kediri Regency Government with letter number 070/277 / 418.62 / 2020.

\section{RESULT}

\section{Recruitment}

Table 1 Characteristics of Participant Demographics $(n=15)$

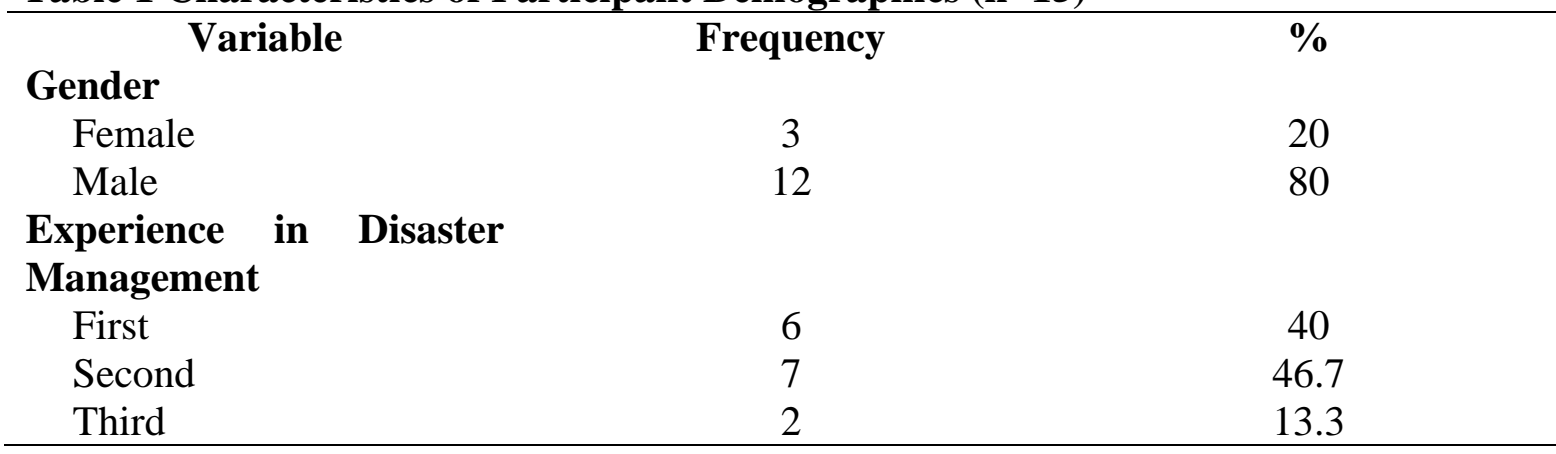

Discussions were held to participants who were active in disaster management Mount Kelud erupted to discuss their experiences regarding disaster management activities. 9 participants from Wonorejo Village, Kepung District and 6 participants from Kebonrejo Village, Puncu District. All participants had been involved in disaster management activities of Mount Kelud eruption, the average experience of being involved in disaster management activities was 2 times.

\section{Themes}

Based on the analysis of data on disaster management for the Kelud Community, two themes were obtained, namely:

\section{Theme 1: Disaster Management Stage}

The disaster management stage based on the knowledge and experience of the participants found that $66.67 \%$ conveyed that the disaster management stages of Mount 


\section{STRADA Jurnal Ilmiah Kesehatan}

DOI: $10.30994 /$ sjik.v9i2.427

ISSN: 2252-3847 (print); 2614-350X (online)

Vol.9 No.2 November 2020 Page.1078-1084

Kelud erupted consisting of three stages, namely before the volcano erupted, when the volcano erupted, after Mount Kelud erupted (EK, IK, PJ), mountain disaster management Kelud erupted consisting of the pre-disaster, disaster and post-disaster stages (MK, UZ, SU, SA, BA, WDD, SPD). $33.33 \%$ of participants said that the stages of disaster management are carried out in two stages, namely pre-disaster and post-disaster (SE, UM, SUI, FA) and the stages when the volcano erupted and after the mountain erupted (DT).

\section{Theme 2: Community Activities at Disaster Management Stage}

Disaster management activities were based on the experiences of participants at the time when Mount Kelud erupted in 2014, namely divided according to the stages of the disaster: 1) Activities in the stages before the disaster $100 \%$ of participants stated that mapping of the red zone area was carried out, mapping of evacuation places, socialization of disaster management to the community, make an agreed early warning, for example when a disaster occurs, always listen to the directions from the loudspeaker at the nearest mosque. $50 \%$ of participants stated that the activities carried out in the stage before the disaster occurred were data collection on the number of residents, the number of vulnerable groups (the number of children under five, pregnant women and the elderly), building cooperation with unaffected villages to accommodate the community during a disaster known as the sister village. 2) Activities during the evacuation of areas in the red and yellow zones, the process of evacuating residents to refugee camps, conducting studies in the evacuation areas related to the needs needed by the community. 3) In the aftermath of the disaster, all the participants returned home to clean the sand on the tiles, worked together to help repair damaged houses, clean roads from piles of sand, prepare for aftershocks of cold lava.

\section{DISCUSSION}

Based on the results of the research obtained, basically the Kelud community was able to adapt and made peace with the natural disaster of the erupting volcano. The community understood about disaster risk reduction this could be proven by the ability of the participants to explain the stages of disaster management and being able to mention the activities carried out in each stage based on experience experienced, besides that the community was also able to reduce the risk of a subsequent cold lava disaster by cleaning eruption materials both at home and along the road through which cold lava flows.

A disaster is a natural or non-natural event that can befall anyone who causes damage to have an impact on biological, psychological and spiritual elements, both individually or in general, including the nation and state (Astuti, W. Vitaria., Rimawati, 2020). Considering the extraordinary impacts, natural disaster management must be carried out using the right principles and methods. Disaster management is all efforts in the form of activities carried out including prevention, rescue, rehabilitation and reconstruction activities, both before, during and after a disaster and reducing the impact of the disaster that occurs (AIPTINAKES, 2018). Disaster management activities are one of the ways carried out in disaster risk reduction (DRR) with the aim of reducing social economic vulnerability to disasters, so that in its implementation it is necessary to develop an internal disaster management mechanism or what is called Community Based Disaster Management (CBDM) a disaster management mechanism which conducted (Sukmana, Oman., 2018). Based on the international declaration states that the disaster risk reduction paradigm is the basis of disaster management where this paradigm encourages the development of community resilience to reduce local vulnerability and increase 


\section{STRADA Jurnal Ilmiah Kesehatan}

DOI: $10.30994 /$ sjik.v9i2.427

ISSN: 2252-3847 (print); 2614-350X (online)

Vol.9 No.2 November 2020 Page.1078-1084

community capacity to better manage disaster risk and impact (Imperiale, Angelo.J., Vancly. Frank, 2018). Community capacity in disaster risk management is one of the characteristics of a major disaster resilient village / district (PERKA, 2012), while the characteristics of a resilient community are 1) Ability to anticipate any threats or hazards that will occur, 2) Ability to fight or avoid these hazards, 3) Ability to adapt to disasters and their impacts, and 4) Ability to recover quickly after a disaster occurs (AIPTINAKES, 2018). The ability to respond to and recover from disasters is also an indicator of community capacity assessment, this is also proven in research (Rahmawati, D., Rachmawati, AT, Prayitno, G., 2018) that socially active villages tend to have a higher capacity. This is directly proportional to the research conducted by Suryani, Irda., et.al (2020) that the minimal role of government and optimal education in community mitigation results in disaster mitigation not yet running well. Community participation in mitigation efforts is also important in reducing the risk of natural disasters. Kelud community participation actions carried out as a mitigation effort include education about disasters, organizing disaster preparedness, creating early warning systems and efforts to save themselves and property (Sejati, Andri Estining., Hasan, Muhammad., Hidayati, Desi Nurul., 2019). Mitigation in Law No. 24 of 2007 is a disaster management effort to minimize the impact of damage due to disasters while minimizing the number of victims (Yudistira, Danu., Nur Fadilah, Nur Ririn., Setiawan, Avi Budi., 2020).

Preparedness in the disasters helps the community in planning actions to be carried out when a disaster occurs, success in evacuation depends on the preparedness of the community, especially the individual himself (Umar, Nurlillah, 2013). Community involvement is a top priority in building effective partnerships in disaster risk reduction, considering that the first to face the disaster is the community itself (Sukmana, Oman, 2018). Preparedness is a series of activities carried out to anticipate disasters through organization and through appropriate and efficient steps (BNPB, 2017).

\section{CONCLUSSION}

Based on the results of research conducted on participants who have been involved in the management of the Mount Kelud eruption in their entirety, the participants were able to have good discussions about their personal experiences when Mount Kelud erupted. The people of Kelud realize that they all have to be able to adapt and make peace with disasters because Mount Kelud will erupt based on a predetermined time and the community realizes that disaster management capacity is one of the factors that can reduce the impact of disaster risk.

\section{ACKNOWLEDGMENTS}

We, researchers, would like to thank the Ministry of Research and Technology / National Research and Innovation Agency (RISTEK-BRIN) for funding Research and Community Service in Higher Education for the 2020 budget year. We also thanks to the Kediri Regency Government's Political and National Unity Agency for the recommendations given, as well as overall participants in this study

\section{REFERENCES}

AIPTINAKES JATIM. (2018). Panduan Teknis Pengabdian Masyarakat : Panduan Kegiatan Peningkatan Ketangguhan Masyarakat oleh Dosen dan Mahasiswa. Malang : Alta Pustaka, Imprint Dioma. 


\section{STRADA Jurnal Ilmiah Kesehatan}

DOI: $10.30994 /$ sjik.v9i2.427

ISSN: 2252-3847 (print); 2614-350X (online)

Vol.9 No.2 November 2020 Page.1078-1084

Astuti, W.Vitaria., Rimawati. (2020). Keperawatan Bencana Dalam Komunitas : Untuk Mahasiswa Keperawatan. Nganjuk : Adjie Media Nusantara

BNPB. (2016). Profil BNPB. http://www.bnpb.go.id/home/sejarah.

BNPB. (2017). Buku pedoman : Latihan Kesiapsiagaan Bencana. Jakarta : Deputi Bidang Pencegahan dan Kesiapsiagaan. Giyono. (2015). Metode Penelitian Kuantitatif, Kualitatif dan R\&D. Bandung : CV.Alfabeta.

Cresswell, J.W. (2011). Designing and Conducting Mixed Methods Research. United States Of America : Sage Publication.

Damayanti, Didit., Wahyu. RG.Pria., Muhanni'ah. (2017). Hubungan Pengetahuan Tentang Manajemen Bencana Dengan Prevention Masyarakat Dalam Menghadapi Bencana Gunung Meletus. Jurnal Ilmu Kesehatan. https://doi.org/10.32831/jik.v5i2.143.

Imperiale, Angelo.J., Vancly. Frank. (2018). Command-and-control, emergency powers, and the failure to observe UnitedNations disaster management principles following the 2009 L'Aquilaearthquake. International Journal Of Disater Risk Reduction. https://doi.org/10.1016/j.ijdrr.2019.101099

Khambali. (2017). Manajemen Penanggulangan Bencana. Ed.I. Yogyakarta : Penerbit Andi.

Moleong, Lexy.J. (2012). Metodologi Penelitian Kualitatif, Edisi Revisi. Bandung : PT Remaja Rosdakarya.

PERKA. (2012) Peraturan Kepala Badan Nasional Penanggulangan Bencana Nomor 1 Tahun 2012 tentang Pedoman Umum Desa/Kelurahan Bencana. Jakarta : Badan Nasional Peanggulangan Bencana

Pusat Vulkano dan Mitigasi Bencana Geologi. (2014). Sejarah Letusan Gunung Kelud

Rahmawati, D., Rachmawati, A.T., Prayitno, G. (2018). Disaster risk reduction of Mount Kelud eruption based on capacity building:A case study in Kasembon District, Malang Regency. Sustinere : Journal Of Environment and Sustainability. https://doi.org/10.22515/sustinere.jes.v2i1.22

Sejati, Andri Estining., Hasan, Muhammad., Hidayati, Desi Nurul. (2019). The level participation in efforts mount Kelud eruption disastermitigation in East Java. Harmoni Sosial : Jurnal Pendidikan IPS. http://dx.doi.org/10.21831/hsipi.v6i1.27847

Sukama, Oman. (2018). Pengetahuan Manajemen Bencana dan Kearifan Sosial di Kabupaten Malang. Jurnal Sosio Konsepsia. https://doi.org/10.33007/ska.v7i3.1417.

Suryani, Irda., Hermon, Dedi., Barlian, Eri., Dewata, Indang., Umar, Iswandi. (2020). Policy Direction for AHP-Based Disaster Mitigation Education the Post Eruption of Dempo Volcano in Pagar Alam City - Indonesia. International Journal of Management and Humanities. http://dx.doi.org/10.35940/ijmh.I0852.054920

Tjahjono, Heru. (2020). Kesiapan Daerah dalam Pengurangan Risiko Bencana.BPBD Jawa Timur

Ula, Nur Mas., Sriartha, I Putu., Citra, I Putu Ananda. (2019). Kesiapsiagaan Masyarakat Terhadap Bencana Banjir Di Desa Pancasari Kecamatan Sukasada Kabupaten Buleleng. Jurnal Pendidikan Geografi Undiksha. http://dx.doi.org/10.23887/jjpg.v7i3.21508

Umar, Nurlailah. (2013). Pengetahuan dan kesiapsiagaan masyarakat menghadapi bencanaBanjir di bolapapu kecamatan kulawi sigi Sulawesi tengah.Jurnal Keperawatan Soedirman. http://dx.doi.org/10.20884/1.jks.2013.8.3.542 


\section{STRADA Jurnal Ilmiah Kesehatan}

DOI: $10.30994 /$ sjik.v9i2.427

ISSN: 2252-3847 (print); 2614-350X (online)

Vol.9 No.2 November 2020 Page.1078-1084

Undang - undang Republik Indonesia Nomor 24 Tahun 2007 Tentang penanggulangan bencana.

Yudistira, Danu., Nur Fadilah, Nur Ririn., Setiawan, Avi Budi. (2020). The Impact of Merapi Mountain Eruption to the Society. Efficient : Indonesian Journal of Development Economis. https://doi.org/10.15.295/efficient.v3il.36695 